\title{
Chemical composition and ruminal degradation kinetics of crude protein and amino acids, and intestinal digestibility of amino acids from tropical forages
}

\section{Lidia Ferreira Miranda ${ }^{1}$, Norberto Mario Rodriguez ${ }^{2}$, Elzânia Sales Pereira ${ }^{3}$, Augusto César de Queiroz ${ }^{4}$, Roberto Daniel Sainz ${ }^{5}$, Patrícia Guimarães Pimentel ${ }^{6}$, Miguel Marques Gontijo Neto ${ }^{7}$}

\footnotetext{
1 Escola de Veterinária da UFMG.

${ }^{2}$ Escola de Veterinária da UFMG. CNPQ Productivity fellow.

${ }^{3}$ Departamento de Zootecnia da UFC. CNPQ Productivity fellow.

${ }^{4}$ Departamento de Zootecnia da UFV. CNPQ Productivity fellow.

${ }^{5}$ Department of Animal Science/University of California.

${ }^{6}$ Departamento de Zootecnia da UFC.

7 Centro Nacional de Pesquisa de Milho e Sorgo/EMBRAPA.
}

\begin{abstract}
The objective of this research was to determine the chemical composition and ruminal degradation of the crude protein (CP), total and individual amino acids of leaves from tropical forages: perennial soybean (Neonotonia wightii), cassava (Manihot esculenta), leucaena (Leucaena leucocephala) and ramie (Boehmeria nivea), and to estimate the intestinal digestibility of the rumen undegradable protein (RUDP) and individual amino acids of leaves from the tropical forages above cited, but including pigeon pea (Cajanus cajan). Three nonlactating Holstein cows were used to determine the in situ ruminal degradability of protein and amino acids from leaves (6,18 and 48 hours of ruminal incubation). For determination of the intestinal digestibility of RUDP, the residue from ruminal incubation of the materials was used for 18 hours. A larger concentration of total amino acids for ramie and smaller for perennial soybean were observed; however, they were very similar in leucaena and cassava. Leucine was the essential amino acid of greater concentration, with the exception of cassava, which exhibited a leucine concentration $40.45 \%$ smaller. Ramie showed 14.35 and $22.31 \%$ more lysine and methionine, respectively. The intestinal digestibility of RUDP varied from 23.56; 47.87; $23.48 ; 25.69$ and $10.86 \%$ for leucaena, perennial soybean, cassava, ramie and pigeon pea, respectively. The individual amino acids of tropical forage disappeared in different extensions in the rumen. For the correct evaluation of those forages, one should consider their composition of amino acids, degradations and intestinal digestibility, once the amino acid composition of the forage does not reflect the amino acid profiles that arrived in the small intestine. Differences between the degradation curves of CP and amino acids indicate that degradation of amino acids cannot be estimated through the degradation curve of CP, and that amino acids are not degraded in a similar degradation profile.
\end{abstract}

Key Words: intestinal digestion, in vitro, metabolizable protein, total aminoacids digestibility

\section{Introduction}

Current systems of protein evaluation for ruminants relay on fragmentary information on the supply of amino acids to the animal. In this regard, the knowledge of the amino acids composition of the undegraded feed protein, which is scarce at the moment, may help to improve the amino acids evaluation of feeds (González et al., 2009). The available amino acids for absorption in the small intestine are derived from dietary protein that escapes from ruminal degradation, from the microbial protein synthesized in the rumen and from the endogenous protein. The relationship between essential and nonessential amino acids acquires importance in the protein portion that escapes from ruminal degradation, once the amino acids of the soluble protein were transformed in that of microbial protein. The crude protein degradation kinetics has been used to predict the degradation of the individual amino acids and its supply to the small intestine (Rulquin \& Verité, 1996). This means that the crude protein degradation kinetics is an appropriate estimate to predict the degradation kinetics of the individual amino acids and, therefore, the supply of amino acids to the small intestine. However, some degree of variability in the total amino acid degradation kinetics in relation to that of crude protein, and among individual amino acids, has been reported (Skórko-Sajko et al., 1994; Dakowski et al., 1996). Rumen degradability of amino acids is one of the most important variables in modern protein evaluation systems for ruminants (Weisbjerg et al., 1996). In the literature only few comparisons between nitrogen and amino acids

Received October 6, 2010 and accepted July 6, 2011.

Corresponding author:elzania@hotmail.com 
degradabilities can be found, and most available results only refer to a single incubation time. Although $\mathrm{N}$ and amino acid degradabilities seem to be nearly similar at the incubation times examined (Rulquin et al., 1993), it is possible that the degradation profile of amino acids differs from that of $\mathrm{N}$, which can result in different effective degradabilities.

The objective of this research was to determine the chemical composition and ruminal degradation of the crude protein, total and individual amino acids of leaves from tropical forages: perennial soybean (Neonotonia wightii), cassava (Manihot esculenta), leucaena (Leucaena leucocephala) and ramie (Boehmeria nivea), and to estimate the intestinal digestibility of the rumen undegradable protein (RUDP) and of individual amino acids of leaves from the tropical forages above cited, but including pigeon pea (Cajanus cajan).

\section{Material and Methods}

Three rumen fistulated nonlactating Holstein cows were used to determine the in situ ruminal degradability of protein and amino acids of leaves from tropical forages: leucaena (Leucaena leucocephala), perennial soybean (Neonotonia wightii), cassava (Manihot esculenta), ramie (Boehmeria nivea) and pigeon pea (Cajanus cajan).

Cows were fed a grass hay:concentrate (70:30 relation) diet, twice a day. The in situ incubation times for the ruminal degradation studies were 6, 18 and 48 hours, following recommendations of Orskov \& McDonald (1979).

Initially, the leaves from the tropical forages were analyzed for dry matter (DM) and crude protein (CP) (AOAC, 1990); and neutral detergent fiber (NDF), with addition of sodium sulphite and thermostable amylase, acid detergent fiber and acid detergent lignin (Van Soest et al., 1991).

Soluble nitrogen fraction was determined by the difference between total nitrogen and trichloroacetic acid insoluble nitrogen (Licitra et al., 1996). The remaining residue was filtered on filter paper Whatman 54, washed with $400 \mathrm{~mL}$ of distilled water, and the remaining residue was transferred to Kjeldahl flask and the residual $\mathrm{N}$ was determined. A portion of the remaining residue was stored for determination of amino acids.

For determination of the intestinal digestibility of the rumen undegradable protein (RUDP), the residue of 18 hours of ruminal incubation was used, since it represents the digesta passage rate of, approximately, 5\%/hours. The simulation of the intestinal digestibility of RUDP was accomplished according to Calsamiglia \& Stern (1995). The residues, from the 18 hours of ruminal incubation time, were analyzed for $\mathrm{N}$ and weighed in a way to provide, approximately, $15 \mathrm{mg}$ of nitrogen (N), and placed into $125 \mathrm{~mL}$ of erlenmeyer flask.

After that, they were incubated for 1 hour at $38^{\circ} \mathrm{C}$ with $10 \mathrm{~mL}$ 0.1 N HCL solution containing $1 \mathrm{~g} / \mathrm{L}$ pepsin at $\mathrm{pH} 1.9$. Subsequently, $\mathrm{pH}$ was neutralized with $0.5 \mathrm{~mL}$ of $1 \mathrm{~N}$ of $\mathrm{NaOH}$ and $13.5 \mathrm{~mL}$ of a buffer-pancreatin solution (0.5 M $\mathrm{KH}_{2} \mathrm{PO}_{4}$ solution, $\mathrm{pH} 7.8$ containing $50 \mathrm{ppm}$ of thymol and $3 \mathrm{~g} / \mathrm{L}$ of pancreatin). Thymol was added to the solution to prevent microbial growth. Residues were vortexed and incubated at $38{ }^{\circ} \mathrm{C}$ for 24 hours in a shaking water bath. Next, the residues were filtered on Whatman filter paper \# 54 by gravity, washed with $400 \mathrm{~mL}$ of distilled water, and the remaining residue was transferred to Kjeldahl flask and the residual $\mathrm{N}$ was determined. A portion of the remaining residue was stored for posterior determination of the amino acids.

The intestinal digestibility of RUDP, in percentage, was calculated as the amount of $\mathrm{N}$ digested after incubation with pepsin and pancreatin, multiplied by 6.25 , which was divided by the amount of incubated protein and multiplied by 100 . From the percentage of the intestinal digestibility of RUDP, the percentage and the protein content of small intestine digestible RUDP were calculated $\left(R_{U D P}\right)$. The amount of each digested amino acids in the small intestine was calculated based on its RUDP content.

The leaves from the tropical forages and fractions from the remaining residues, after in situ ruminal degradability and intestinal digestibility were ground to powder in a porcelain mill, and sieved in $0.25 \mathrm{~mm}$ (60 mesh) sieve. Afterward, they were hydrolyzed with $6 \mathrm{~N}_{2}$ hydrochloric acid at $110{ }^{\circ} \mathrm{C}$ for 24 hours under an $\mathrm{N}$ atmosphere. After hydrolysis, they were filtered on a filter paper, rotary evaporated and ultracentrifuged at $13.000 \times \mathrm{G}$ for 3 minutes and ultrafiltrated though a $0.45 \mathrm{~mm}$ teflon membrane (Llames \& Fontaine, 1994).

For determination of sulfur amino acids (methionine, cystine and cysteine), samples were oxidized with performic acid, to avoid degradation during the process of acid hydrolysis. Methionine was converted into methionine sulfone, and cystine and/or cysteine into cysteic acid (Cunniff, 1995).

Amino acid analyses were accomplished by HPLC (high-performance liquid chromatography), in Shumadzu CL 10 chromatograph, following methodology proposed by Ishida et al. (1981). The system consisted of a binary gradient of elution, separation step with a sodium type cation-exchange column, and in the post-column derivatization the reaction step with sodium hypochlorite and o-phtalaldehyde, and detection using a filter-type fluorometric detector with xenon lamp. 
Amino acids were expressed as percentage of crude protein from each residue of the respective tropical forages. The degradation curves of the individual amino acids were adjusted using the TCA soluble fraction, as an estimate of zero time, and the in situ ruminal degradation incubation times of 6, 18 and 48 hours, by Proc NLIN of SAS (Statistical Analyses System, version 8.0), according to the equation proposed by Orskov \& McDonald (1979) and reparametrization by McDonald (1981):

$\mathrm{D}_{1}=\mathrm{a}$, for $0 \leq \mathrm{t} \leq \mathrm{L}$

$\mathrm{D}_{1}=\mathrm{a}^{\prime}+\mathrm{b}^{\prime}(1-\exp (-\mathrm{ct}))$, for $\mathrm{t}>\mathrm{L}$

where $D_{1}$ is the percentage degradation of the crude protein or of the amino acids in the time t; a corresponds to the initial substrate solubilization, obtained at zero time; a' and b' are scale parameters of the model that do not have biological meaning; $c$ is the degradation rate of the potentially degradable soluble fraction (b), which it is not represented in the model, but is calculated by subtracting from the asymptotic (a'+ b') the value of a; and $L$ corresponds to the latency period, calculated by the equation:

$\mathrm{L}=\left\{\ln \left[\mathrm{b} /\left(\mathrm{a}^{\prime}+\mathrm{b}^{\prime}-\mathrm{a}\right)\right]\right\} / \mathrm{c}$

The effective ruminal degradation was calculated using the passage rate of $5 \% / h$, according to the model proposed by McDonald (1981):

$\left.\mathrm{ED}=\mathrm{a}+\left(\underline{\mathrm{b}^{\prime} . \mathrm{c}}\right) \exp \{-\mathrm{c}+\mathrm{kp}) \cdot \mathrm{L}\right\}$,

$$
(\mathrm{c}+\mathrm{kp})
$$

where ED is the effective ruminal degradation of the analyzed nutritive component, and $\mathrm{kp}$ is the passage rate. The linear regression equations were calculated using the amino acid profiles of the original forage (independent) and the amino acid profiles of the respective remaining residues after 18 hours of ruminal incubation (dependent) by PROC REG of the SAS statistical package.

\section{Results and Discussion}

There was a considerable variation in the soluble protein fraction of tropical forages (Table 1), which reinforces the proposal of using, in ruminant feeding, the mechanistic concept that attempts to avoid the use of empiric entities that are generally associated with erroneous predictions and present limited inference space (Fox et al., 1992; Russell et al., 1992; Van Soest, 1994). The static concept could be used when the CP content was evaluated among tropical forages, leucaena (25.45\%), perennial soybean (26.01\%) and ramie (27.58\%), only under the absolute value form.

With regard to the amino acid composition of tropical forages, it could be pointed out that the percentage of total amino acids in the crude protein ranged from 87.23 to $95.17 \%$ for perennial soybean and ramie, respectively (Table 1). However, for leucaena, perennial soybean and cassava, the amount of total amino acids was very similar. Lysine and

Table 1 - Chemical composition of leaves from leucaena, perennial soybean, cassava, ramie and pigeon pea (\%DM)

\begin{tabular}{|c|c|c|c|c|c|}
\hline Item & Leucaena & Perennial soybean & Cassava & Ramie & Pigeon pea \\
\hline Dry matter $(\mathrm{DM})(\%)^{1}$ & 87.95 & 86.59 & 89.13 & 88.9 & 90.31 \\
\hline Neutral detergent fiber & 37.06 & 50.06 & 43.74 & 26.18 & 58.22 \\
\hline Acid detergent fiber & 12.47 & 23.79 & 21.84 & 15.74 & 33.97 \\
\hline Crude protein (CP) & 25.45 & 26.01 & 37.63 & 27.58 & 19.98 \\
\hline Soluble crude protein & 33.92 & 26.93 & 27.01 & 33.69 & 16.87 \\
\hline Acid detergent insoluble protein & 7.59 & 6.38 & 9.58 & 2.83 & 26.68 \\
\hline Total amino acid $^{2}$ & 87.72 & 87.23 & 87.50 & 95.17 & 92.20 \\
\hline Essential amino acid & 44.45 & 44.83 & 42.20 & 48.06 & 46.52 \\
\hline Arginine & 6.37 & 5.98 & 7.19 & 6.73 & 5.71 \\
\hline Phenylalanine & 5.52 & 5.25 & 4.54 & 5.46 & 5.53 \\
\hline Histidine & 2.38 & 2.88 & 2.80 & 3.12 & 2.70 \\
\hline Isoleucine & 4.48 & 4.54 & 4.50 & 4.95 & 5.06 \\
\hline Leucine & 8.02 & 7.98 & 3.32 & 8.07 & 8.76 \\
\hline Lysine & 5.89 & 6.36 & 5.49 & 6.41 & 5.86 \\
\hline Methionine & 2.09 & 2.15 & 2.30 & 2.66 & 2.02 \\
\hline Threonine & 4.13 & 4.25 & 3.47 & 4.79 & 4.63 \\
\hline Valine & 5.58 & 5.44 & 8.58 & 5.89 & 6.26 \\
\hline Nonessential amino acids & 43.28 & 42.40 & 45.30 & 47.11 & 45.68 \\
\hline Alanine & 5.25 & 5.44 & 4.65 & 5.69 & 5.96 \\
\hline Aspartate & 8.21 & 9.11 & 11.71 & 11.96 & 9.43 \\
\hline Cystine & 0.45 & 0.52 & 0.53 & 1.44 & 0.42 \\
\hline Glycine & 4.99 & 5.06 & 4.08 & 5.48 & 5.28 \\
\hline Glutamate & 11.73 & 10.57 & 11.72 & 10.49 & 10.21 \\
\hline Proline & 4.93 & 4.90 & 4.32 & 4.68 & 6.28 \\
\hline Serine & 4.05 & 4.04 & 3.73 & 4.31 & 4.55 \\
\hline Tyrosine & 3.67 & 2.77 & 4.57 & 3.06 & 3.54 \\
\hline
\end{tabular}

\footnotetext{
${ }^{1} \mathrm{~g} / 100 \mathrm{~g}$ DM.
}

$2 \mathrm{~g} / 100 \mathrm{~g}$ CP. 
methionine concentrations, among the tropical forages, were similar, having as average, 13.28 and $4.97 \%$ of the total essential amino acids, respectively. NRC (2001) considers lysine and methionine as the two essential limiting amino acids, for growth and milk production, and reports that most feeds have low lysine (Lys) and methionine (Met) concentrations and, particularly lysine, in the total essential amino acids.

Tropical forages presented a large concentration of the referred amino acids (Met and Lys), because they had concentrations of 13.75 and $22.45 \%$, superior to the average observed for lysine and methionine concentrations (expressed in percentage of total essential amino acids) of legumes and grass, described in NRC (2001). Methionine concentrations in tissue and milk are very similar to the average concentration of the tropical forages of this research, 5.30 vs. $4.97 \%$ of the total of essential amino acids, respectively.

For the amino acid composition of forages, a larger total amino acid concentration for ramie, and a smaller one for perennial soybean was recorded, although very close to leucaena and cassava (95.17; 87.23; 87.72 and $87.50 \mathrm{~g} / 100 \mathrm{~g}$ $\mathrm{CP}$, respectively). It can be observed that leucine was the essential amino acid with greatest concentration, except for cassava, which presented a leucine concentration $40.45 \%$ smaller in relation to the average of the other forages. Ramie had 14.35 and $22.31 \%$ more lysine and methionine, respectively, as compared with cassava, which presented smaller concentrations of these amino acids.

The estimates of coefficients $a, b$ and $c$ of the equations adjusted for $C P$, total, essential, nonessential and individual amino acids, as well as the lag phase and the effective degradation of leucaena, perennial soybean, cassava, and ramie showed some kind of variations among the tropical forages (Table 2). For all tropical forages, the effective degradation of crude protein was smaller comparative to the degradation of the essential, nonessential and individual amino acids, and those results were in agreement with Komprda \& Standara (1992) reports.

The difference between the effective degradation of the total amino acids and of CP presented variations, being $13.92 \%$ larger for the total amino acids of cassava, and perennial soybean. However, results differing from this study were obtained by Skiba et al. (1996), who observed smaller effective degradation for the total amino acids and larger effective degradations for CP. Results from SkórkoSajko et al. (1994) demonstrated similar values for CP and total of amino acids degradation, suggesting that differences could happen between the CP and the total amino acids degradation, as well as for the individual amino acid degradations. There was considerable variation between values for the individual and total amino acids degradation for cassava. Different behavior was observed for leucaena, perennial soybean and ramie (Table 2 ). Such variation was observed in cassava due to the difference between the total amino acid and methionine degradation (an essential amino acid with larger degradation in cassava). It was observed, between the essential amino acids, methionine and lysine, very close or smaller degradation than that of total amino acids in leucaena. A similar behavior was observed for the ramified amino acids of the leucaena, perennial soybean and ramie. Similar results were obtained by Skiba et al. (1996), who observed that methionine and lysine, in the most studied forages, presented similar degradation to the total amino acids degradation, especially for longer periods of ruminal incubation. However, for the perennial soybean and cassava, methionine was the amino acid of greatest degradation, as reported by Komprda \& Standara (1992), in a degradation study using alfalfa. Methionine was considered to be an amino acid of high resistance to ruminal degradation (Taminga, 1979), although some authors suggest that degradation is dependent on the feed (Erasmus et al., 1994). For leucaena, the effective degradation of methionine was smaller when compared with the effective degradation of the total amino acids, which was also previously observed by Weisbjerg et al. (1996). Then, it could be inferred that the smallest ruminal methionine degradation is important information to predict the methionine that will arrive at the small intestine.

The differences observed between the CP and the amino acids degradation and among the amino acids themselves indicated that the degradation of the amino acids could not be estimated through the CP degradation and that the amino acids are not degraded in the same manner. The effective degradation of lysine and methionine are of special interest, because those amino acids are considered essential limiting amino acids in certain physiological stages (Rulquin et al., 1993). The effective degradation of lysine was similar to the degradation of the total amino acids only for leucaena and cassava, and for perennial soybean. In leucaena (Table 2), phenylalanine and glutamine were the amino acids that showed greatest degradation (76.39 and 78.97\%, respectively). The behavior of smaller degradation showed by isoleucine and the close behavior of leucine and valine compared with the total amino acids degradation coud be explained by the viscous solubility behavior when hydrophobic polypeptides were moisturized by ruminal fluid, reducing the CP disappearance, although allowing selective degradation of some amino acids by the ruminal microorganisms. However, it should be 
Table 2 - Degradation kinetics of the crude protein and amino acids of leucaena, perennial soybean, cassava and ramie

\begin{tabular}{|c|c|c|c|c|c|c|c|c|c|c|c|c|}
\hline \multirow{3}{*}{$\begin{array}{l}\text { Protein } \\
\text { fraction }\end{array}$} & \multicolumn{12}{|c|}{ Degradation kinetics } \\
\hline & \multicolumn{3}{|c|}{ Parameter } & \multirow[t]{2}{*}{$r^{2}$} & \multirow[t]{2}{*}{ Lag time (h) } & \multirow[t]{2}{*}{ ED } & \multicolumn{3}{|c|}{ Parameter } & \multirow[t]{2}{*}{$\mathrm{r}^{2}$} & \multirow[t]{2}{*}{ Lag time (h) } & \multirow[t]{2}{*}{$\mathrm{ED}$} \\
\hline & $a$ & $b$ & c & & & & $a$ & $b$ & c & & & \\
\hline & & & Leucaena & & \multicolumn{8}{|c|}{ Perennial soybean } \\
\hline CP & 33.90 & 57.84 & 0.0613 & 99.37 & 10.86 & 52.43 & 26.9 & 66.23 & 0.2712 & 98.83 & 4.08 & 72.54 \\
\hline TAA & 56.54 & 41.60 & 0.1074 & 99.60 & 8.85 & 74.78 & 41.51 & 57.28 & 0.3203 & 97.56 & 3.18 & 83.77 \\
\hline EAA & 56.68 & 41.44 & 0.1074 & 99.61 & 9.16 & 74.57 & 43.38 & 55.40 & 0.3270 & 97.56 & 3.45 & 83.82 \\
\hline Arg & 59.41 & 39.18 & 0.1023 & 99.70 & 9.47 & 75.80 & 45.17 & 53.96 & 0.2852 & 98.59 & 3.30 & 84.10 \\
\hline Phe & 61.14 & 36.92 & 0.1084 & 99.72 & 10.09 & 76.39 & 45.16 & 53.55 & 0.3379 & 99.42 & 3.88 & 83.58 \\
\hline His & 61.39 & 36.71 & 0.1061 & 99.79 & 10.71 & 76.00 & 37.79 & 61.04 & 0.3366 & 99.65 & 3.32 & 82.80 \\
\hline Ile & 54.16 & 43.93 & 0.1051 & 99.69 & 8.85 & 73.28 & 40.05 & 58.58 & 0.3166 & 97.31 & 3.32 & 82.90 \\
\hline Leu & 57.94 & 40.21 & 0.1076 & 99.60 & 9.62 & 74.90 & 42.56 & 56.33 & 0.3346 & 97.07 & 3.47 & 83.76 \\
\hline Lys & 58.52 & 39.32 & 0.1054 & 99.56 & 9.85 & 74.81 & 46.46 & 52.11 & 0.3413 & 94.07 & 3.29 & 85.02 \\
\hline Met & 39.64 & 58.61 & 0.1189 & 97.64 & 5.15 & 71.53 & 49.02 & 49.79 & 0.3587 & 96.87 & 3.68 & 85.36 \\
\hline Thr & 59.18 & 38.92 & 0.1081 & 99.64 & 9.81 & 75.47 & 45.71 & 53.06 & 0.3242 & 98.01 & 3.54 & 84.24 \\
\hline Val & 56.38 & 41.77 & 0.1060 & 99.28 & 8.66 & 74.79 & 38.51 & 60.45 & 0.2704 & 91.59 & 2.80 & 82.85 \\
\hline NEAA & 58.74 & 39.29 & 0.1065 & 99.49 & 10.00 & 74.96 & 39.41 & 59.33 & 0.2960 & 97.85 & 2.65 & 83.86 \\
\hline Ala & 54.80 & 42.99 & 0.1059 & 99.35 & 10.38 & 72.18 & 35.87 & 62.94 & 0.3320 & 97.41 & 3.11 & 82.68 \\
\hline Asp & 56.71 & 41.29 & 0.1110 & 99.68 & 8.78 & 75.06 & 42.77 & 56.12 & 0.2985 & 96.75 & 2.70 & 84.78 \\
\hline Cys & 48.60 & 50.92 & 0.0855 & 97.92 & 2.57 & 76.85 & 46.48 & 52.32 & 0.1860 & 91.96 & -0.30 & 88.33 \\
\hline Gly & 53.77 & 44.10 & 0.1081 & 99.50 & 9.15 & 72.86 & 40.40 & 58.30 & 0.3008 & 97.77 & 2.95 & 83.54 \\
\hline Gln & 60.57 & 38.08 & 0.1088 & 99.55 & 6.99 & 78.97 & 40.65 & 58.39 & 0.3035 & 97.68 & 2.65 & 84.57 \\
\hline Pro & 58.42 & 39.29 & 0.1081 & 99.25 & 9.44 & 75.18 & 41.53 & 56.85 & 0.3639 & 98.26 & 3.39 & 83.72 \\
\hline Ser & 61.32 & 36.54 & 0.1092 & 99.65 & 10.31 & 76.29 & 44.01 & 54.55 & 0.3281 & 97.79 & 3.36 & 84.03 \\
\hline \multirow[t]{2}{*}{ Ty r } & 56.85 & 41.15 & 0.1064 & 99.55 & 9.71 & 74.08 & 23.55 & 75.21 & 0.3395 & 98.89 & 2.82 & 80.49 \\
\hline & & & Cassava & & & & & Ramie & & & & \\
\hline CP & 27.01 & 66.64 & 0.1185 & 97.91 & 2.56 & 68.25 & 33.69 & 61.63 & 0.0613 & 98.31 & 5.87 & 68.53 \\
\hline TAA & 47.34 & 51.36 & 0.1938 & 96.03 & 4.05 & 80.69 & 56.02 & 43.48 & 0.1074 & 96.80 & 5.80 & 82.70 \\
\hline EAA & 48.23 & 50.28 & 0.1962 & 98.08 & 4.82 & 79.72 & 56.98 & 42.49 & 0.1074 & 96.52 & 6.10 & 82.65 \\
\hline Arg & 51.52 & 47.37 & 0.2117 & 85.08 & 5.54 & 80.57 & 61.23 & 38.29 & 0.1023 & 97.11 & 6.54 & 83.82 \\
\hline Phe & 45.75 & 52.67 & 0.1887 & 95.81 & 4.48 & 79.02 & 51.91 & 47.57 & 0.1084 & 97.16 & 5.98 & 80.86 \\
\hline His & 63.85 & 35.01 & 0.1969 & 97.30 & 5.85 & 84.69 & 58.65 & 40.84 & 0.1061 & 96.33 & 6.24 & 83.19 \\
\hline Ile & 49.79 & 48.41 & 0.1884 & 95.43 & 5.20 & 79.29 & 53.73 & 45.69 & 0.1051 & 97.40 & 6.11 & 81.35 \\
\hline Leu & -13.46 & 110.93 & 0.2056 & 92.58 & 2.53 & 65.16 & 51.73 & 47.74 & 0.1076 & 97.01 & 5.89 & 80.89 \\
\hline Lys & 46.18 & 52.31 & 0.1820 & 95.59 & 4.11 & 79.59 & 67.86 & 31.59 & 0.1054 & 93.82 & 7.21 & 85.87 \\
\hline Met & 76.88 & 22.31 & 0.1830 & 97.87 & 7.16 & 89.12 & 59.90 & 39.67 & 0.1189 & 96.86 & 5.56 & 84.46 \\
\hline Thr & 48.08 & 50.48 & 0.1899 & 96.49 & 4.84 & 79.44 & 57.00 & 42.46 & 0.1081 & 96.91 & 5.97 & 82.78 \\
\hline Val & 65.50 & 33.04 & 0.2172 & 93.48 & 6.99 & 84.43 & 50.81 & 48.63 & 0.1060 & 94.12 & 5.61 & 80.79 \\
\hline NEAA & 46.35 & 52.43 & 0.1885 & 94.40 & 3.33 & 81.42 & 54.93 & 44.588 & 0.1065 & 97.49 & 5.36 & 82.94 \\
\hline Ala & -16.70 & 115.29 & 0.1904 & 95.57 & 0.52 & 72.28 & 55.59 & 43.86 & 0.1059 & 96.94 & 6.17 & 82.01 \\
\hline Asp & 53.73 & 45.47 & 0.1879 & 96.04 & 2.36 & 85.64 & 63.78 & 35.84 & 0.1110 & 96.74 & 5.12 & 86.46 \\
\hline Cys & 76.38 & 22.56 & 0.1981 & 98.50 & 5.12 & 90.32 & 58.64 & 41.18 & 0.0855 & 96.66 & 1.19 & 90.30 \\
\hline Gly & 37.83 & 60.59 & 0.1888 & 95.63 & 3.90 & 77.24 & 52.64 & 46.71 & 0.1081 & 96.77 & 5.70 & 81.71 \\
\hline Gln & 54.22 & 44.81 & 0.1898 & 95.50 & 3.22 & 84.42 & 48.71 & 50.73 & 0.1088 & 96.92 & 5.32 & 80.95 \\
\hline Pro & 49.68 & 48.63 & 0.1920 & 93.08 & 4.13 & 81.06 & 56.90 & 42.5 & 0.1081 & 98.09 & 6.30 & 82.44 \\
\hline Ser & 56.77 & 42.00 & 0.1913 & 96.30 & 4.83 & 82.92 & 56.13 & 43.36 & 0.1092 & 96.50 & 5.56 & 82.89 \\
\hline Tyr & 58.86 & 40.08 & 0.1751 & 79.95 & 5.46 & 82.59 & 47.06 & 52.52 & 0.1064 & 97.22 & 5.56 & 79.61 \\
\hline
\end{tabular}

clear that, from all the amino acids, methionine, presented a smaller effective degradation in all the studied forages. For cassava (Table 2), methionine and cystine were the amino acids of greatest degradation, and leucine, the smallest. However, as well as for leucaena, perennial soybean and ramie, isoleucine, leucine and valine presented a very close or smaller degradation than that of total amino acids, demonstrating that ramified amino acids seem to be more resistant to ruminal degradation, what has been suggested by other authors (Erasmus et al., 1994; Harstad
\& Prestlokken, 2000). Concerning lag time, it is important to observe that the effective degradation of crude protein is not dependent only on ruminal kinetics of the protein particles degradation, but also on retention time (Orskov \& McDonald, 1979). However, the interpretation should be expanded to overcome the results of the forages that present lag phase before the beginning of the degradation of the potentially degradable fraction (McDonald, 1981). Cassava and perennial soybean were the tropical forages that presented smaller lag time for crude protein and total amino 
acids ( 2.56 and $4.05 ; 4.08$ and 3.18 hours, respectively). The estimate of the CP lag phase of the forages was larger than for the total of amino acids, except for cassava, which showed a different behavior. Except for cassava, lower correlation between the effective degradation of the essential amino acids and the lag time was observed.

The ruminal degradation and the digestion of the crude protein (CP), essential amino acids, non essential amino acids, and individual amino acids of leucaena, perennial soybean, cassava, ramie and pigeon pea showed some kind of variations between the forages (Tables 3 and 4). The percentage of amino acids degraded in the rumen varied from 78.61 to $87.20 \%$ for alanine and glutamine, 97.06 to $98.51 \%$ for cystine and methionine, 92.85 to $97.18 \%$ for leucine and cystine; 96.38 to $98.38 \%$ for valine and cystine, and 71.9 to $83.26 \%$ for phenylalanine and cystine, in leucaena, perennial soybean, cassava, ramie and pigeon pea, respectively. Therefore, differences exist among the degradation of the individual amino acids, but, as it can be observed (Tables 3 and 4) for perennial soybean, cassava and ramie, those differences were of small magnitude. The tropical forages presented high ruminal degradation, deserving special attention when used in significant amounts in the ration, once it may lead to losses of $\mathrm{N}$ in the rumen, demanding the inclusion of energy sources of fast degradation. Among the forages, leucaena and pigeon pea (Tables 3 and 4) presented the largest amount of RUDP (45.57 and $74.54 \%$ vs. 8.12; 11.93 and 13.88 for perennial soybean, cassava and ramie, respectively) and, consequently, smaller degradation of the amino acids.

In relation to the enzymatic intestinal digestibility of the amino acids non degraded in the rumen, the values observed ranged varied from $10.86 ; 8.17$ and $11.37 \%$ for $C P$, TAA and EAA, respectively, for the pigeon pea, to 47.87; 57.89 and $54.65 \%$ for perennial soybean. Perennial soybean and cassava were the forages that showed a high intestinal digestibility both for $\mathrm{CP}$ and total and individual amino acids. However, those values could be underestimated when compared with the mobile nylon bags technique, due to the microbial fermentation in the large intestine, of the amino acids not digested in the small intestine, which tends to increase the intestinal digestibility estimates by the mobile nylon bags technique. In agreement with Dakowiski et al. (1996), the intestinal digestibility of crude protein and of the amino acids was smaller after ruminal incubation, because of the amount of RUDP and of its indigestible fraction in the small intestine, leading to smaller digestibility of RUDP, when compared with the protein of the feed (Hvelplund et al., 1992). Therefore, one of the reasons of the low intestinal digestibility of the residues of rumen incubation could be in function of the high ruminal degradation of the forages. The observed values of intestinal digestibility of RUDP of the forages were below the informed by the nutritional requirements systems that give support to the diet formulations for ruminants, because those systems use values from 0.80 to 0.85 for the apparent intestinal digestibility of RUDP, with the value of 0.80 adopted by the NRC (1985); and of 0.90X (UDP - 6.25 ADIN), used by AFRC (1993). However, the NRC (2001) system considers that the intestinal digestibility of RUDP could vary from 50 to $100 \%$. The values observed in this research were $23.56 ; 47.87 ; 23.48 ; 25.69$ and $10.86 \%$ for leucaena, perennial soybean, cassava, ramie and pigeon, respectively (Tables 3 and 4). This fact can be attributed to the high ruminal degradation, and the protein that escapes to ruminal degradation corresponds to the fraction of more difficult digestion. In the peculiar case of pigeon pea, which showed a high ADIP (Table 1), it is possible that the protein which escapes the ruminal fermentation was associated with the fiber, what explains the low intestinal digestibility of the amino acids and, mainly, of crude protein.

The forages that supply larger content of RUDP ${ }_{D}$ (digestible rumen undegradable protein, \% CP or g/kg DM) were leucaena, cassava and pigeon pea, due to the ruminal escape, and intestinal digestibility (23.56; 23.48 and 10.86 vs. 47.87 and 25.69, for leucaena, cassava, pigeon pea, perennial soybean and ramie, respectively) once leucaena and cassava showed intermediary intestinal digestibility. Tropical forages of larger ruminal degradation had the smallest amino acids RUDP $_{\mathrm{D}}$ contents in $\mathrm{g} / \mathrm{kg}$ DM. In perennial soybean, cassava and ramie, the intestinal digestibility for the total amino acids was larger than the protein, as reported by Skórko-Sajko et al. (1994) for forages and Dakowski et al. (1996), with colza meal. Although in leucaena the intestinal digestibility for total of amino acids was similar to the protein (24.04 and 23.56, respectively), for pigeon pea, the crude protein showed larger digestibility (10.86 vs.8.17\%). Those results demonstrate that the intestinal digestibility of the crude protein does not accurately predict the intestinal digestibility of the amino acids, which could be, however, a function of the feed. On the other hand, Masoero et al. (1994) reported that the intestinal digestibility of the total amino acids of the RUDP were compatible with the intestinal digestibility of the protein for most of the feeds, except for the feeds of low digestibility and high fiber content.

Cystine was the amino acid that presented the greatest intestinal digestibility in leucaena, ramie and pigeon pea, which is in agreement with previous study of Weisbjerg et al. (1996), evaluating concentrate feeds. 


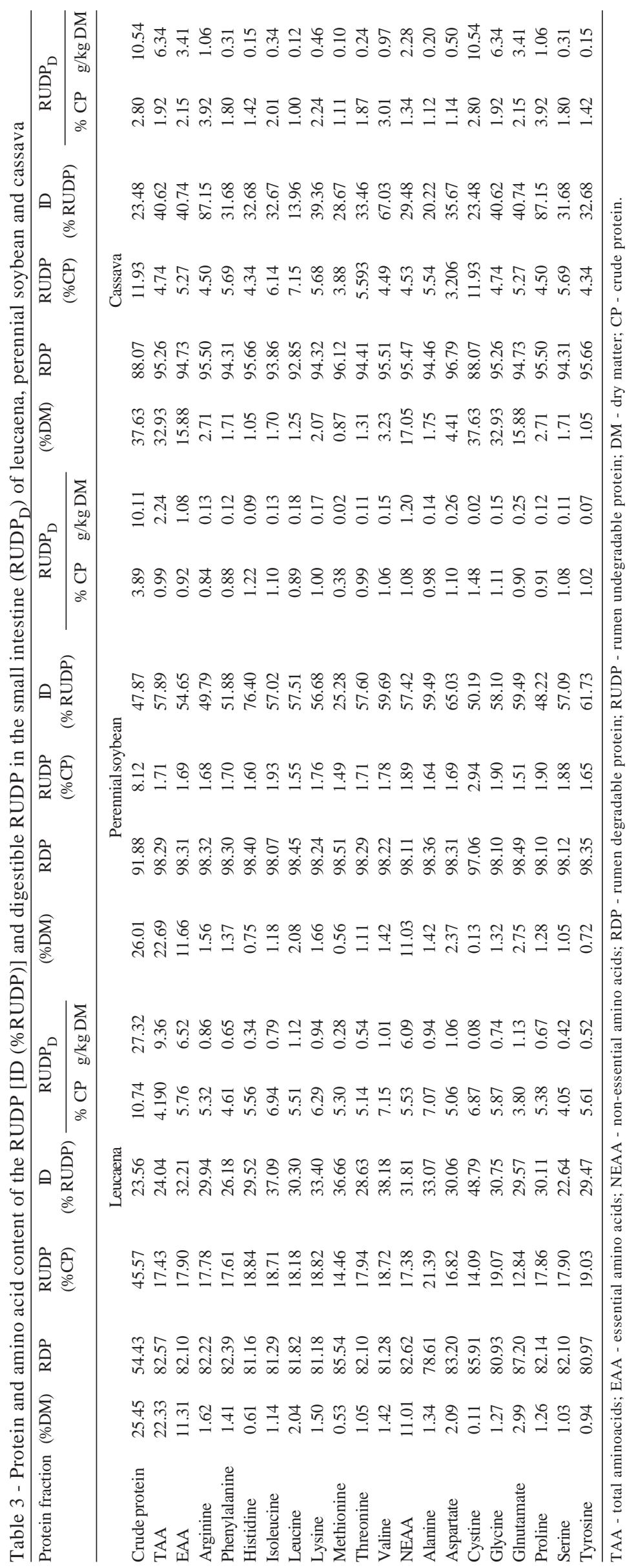


Greater intestinal digestibilitywas observed for methionine in ramie (44.44\% of CP), although smaller in perennial soybean (25.28\% CP), which reinforces the fact that the digestibility of the amino acids could be an intrinsic characteristic of the forage. Comparing the data from Tables 3 and 4, one could infer that the use of the indexes of intestinal digestion of 100; 100 and $80 \%$ for the B1, B2 and B3 fractions that escape from the rumen, according to Sniffen et al. (1992) to estimate RUDP ${ }_{\mathrm{D}}$, tend to overestimate the intestinal digestibility of all feeds. This fact could cause a serious misunderstanding in the prediction of the metabolizable protein and of the amino acid profile that reaches the small intestine and, consequently, the animal performance. Perennial soybean only supplies $2.24 \mathrm{~g} / \mathrm{kg}$ DM of total amino acids in the small intestine, which is not very lower than ramie and pigeon pea (3.03 and $3.7 \mathrm{~g} / \mathrm{kg}$ $\mathrm{DM})$. Based on these data, and in relations to the RUDP (g/kg DM), leucaena (9.36), cassava (6.34) and pigeon pea (3.70) would be the best protein sources. Facing these results, it is observed the need for a selection between the several tropical forages, according to ruminal degradation and intestinal digestibility of the non-degraded protein, to see in which situation it should be supplemented and which of these must be the supplement characteristics, to attend the microorganism requirements for larger protein synthesis (Mupeta et al., 1997). Research with infusion of amino acids in the duodenum has led to conclusions that lysine and methionine are the first limiting amino acids for production and synthesis of milk protein, from which it has been suggested that the amount of lysine and methionine, as a percentage of the total essential amino acids in the duodenal digesta, adequate for synthesis of milk and casein, would be 15 and 5\%, respectively (Schwab et al., 1992). In that way, protein supplements with low contents or unbalanced in lysine and methionine could result in a lack of response or reduction in the production and in the amount of protein secreted in the milk (Schwab et al., 1992). When tropical forages of this study are compared with the amino acid profiles observed by Schwab et al. (1992), considering the percentage of essential amino acids, it is noticed that perennial soybean and cassava showed lysine:methionine relations of 14.79:4.27 and 15.26:4.36, respectively, which resemble that of the milk protein.

In Brazil, there is almost no data on the quantification of the amino acids, their ruminal dynamic, as well as estimates of their intestinal digestibility. Then, this study comes to collaborate with the construction of a database that in the future could be useful in ration formulations for ruminants fed with tropical forages.

Table 4 - Protein and amino acids content of the RUDP (ID) and digestible RUDP in the small intestine (RUDP ${ }_{\mathrm{D}}$ ) of leucaena, perennial soybean and cassava

\begin{tabular}{|c|c|c|c|c|c|c|c|c|c|c|c|c|}
\hline \multirow{2}{*}{$\begin{array}{l}\text { Protein } \\
\text { fraction }\end{array}$} & \multirow[t]{2}{*}{$(\% \mathrm{DM})$} & \multirow[t]{2}{*}{ RDP } & \multirow{2}{*}{$\begin{array}{l}\text { RUDP } \\
(\% \mathrm{CP})\end{array}$} & \multirow{2}{*}{$\begin{array}{ll} & \text { ID } \\
(\% & \text { RUDP })\end{array}$} & \multicolumn{2}{|c|}{$\mathrm{RUDP}_{\mathrm{D}}$} & \multirow[t]{2}{*}{ (\%DM) } & \multirow[t]{2}{*}{ RDP } & \multirow{2}{*}{$\begin{array}{l}\text { RUDP } \\
(\% \mathrm{CP})\end{array}$} & \multirow{2}{*}{$\begin{array}{ll} & \text { ID } \\
(\% & \text { RUDP })\end{array}$} & \multicolumn{2}{|c|}{ RUDP $_{D}$} \\
\hline & & & & & $\% \mathrm{CP}$ & g/kg DM & & & & & \% CP & $\mathrm{g} / \mathrm{kg} \mathrm{DM}$ \\
\hline & & & Ramie & & & & & & igeon pe & & & \\
\hline Crude protein & 27.58 & 86.12 & 13.88 & 25.69 & 3.57 & 9.84 & 19.98 & 25.41 & 74.59 & 10.86 & 8.10 & 16.18 \\
\hline TAA & 26.25 & 96.81 & 3.19 & 36.28 & 1.16 & 3.03 & 18.42 & 75.44 & 24.56 & 8.17 & 2.01 & 3.70 \\
\hline EAA & 13.26 & 96.61 & 3.39 & 38.19 & 1.30 & 1.72 & 9.29 & 74.51 & 25.49 & 11.37 & 2.90 & 2.69 \\
\hline Arginine & 1.86 & 96.62 & 3.38 & 42.70 & 1.44 & 0.27 & 1.14 & 77.05 & 22.95 & 18.89 & 4.33 & 0.49 \\
\hline Phenylalanine & 1.51 & 96.43 & 3.57 & 33.97 & 1.21 & 0.18 & 1.11 & 71.79 & 28.21 & 8.73 & 2.46 & 0.27 \\
\hline Histidine & 0.86 & 96.72 & 3.28 & 38.13 & 1.25 & 0.11 & 0.54 & 73.67 & 26.33 & 12.85 & 3.38 & 0.18 \\
\hline Isoleucine & 1.37 & 96.40 & 3.60 & 34.35 & 1.24 & 0.17 & 1.01 & 73.00 & 27.00 & 9.46 & 2.55 & 0.26 \\
\hline Leucine & 2.23 & 96.44 & 3.56 & 36.21 & 1.29 & 0.29 & 1.75 & 73.12 & 26.88 & 4.18 & 1.12 & 0.20 \\
\hline Lysine & 1.77 & 96.67 & 3.33 & 39.97 & 1.33 & 0.23 & 1.17 & 78.05 & 21.95 & 8.68 & 1.91 & 0.22 \\
\hline Methionine & 0.73 & 97.14 & 2.86 & 44.44 & 1.27 & 0.09 & 0.40 & 74.09 & 25.91 & 23.12 & 5.99 & 0.24 \\
\hline Threonine & 1.32 & 96.64 & 3.36 & 36.84 & 1.24 & 0.16 & 0.93 & 74.59 & 25.41 & 10.64 & 2.70 & 0.25 \\
\hline Valine & 1.63 & 96.38 & 3.62 & 37.12 & 1.34 & 0.22 & 1.25 & 75.22 & 24.78 & 5.74 & 1.42 & 0.18 \\
\hline NEAA & 12.99 & 97.08 & 2.92 & 36.79 & 1.07 & 1.40 & 9.13 & 76.93 & 23.07 & 8.64 & 1.99 & 1.82 \\
\hline Alanine & 1.57 & 96.49 & 3.51 & 35.41 & 1.24 & 0.20 & 1.19 & 75.61 & 24.39 & 8.17 & 1.99 & 0.24 \\
\hline Aspartate & 3.30 & 97.61 & 2.39 & 37.64 & 0.90 & 0.30 & 1.89 & 76.97 & 23.03 & 4.13 & 0.95 & 0.18 \\
\hline Cystine & 0.40 & 98.83 & 1.17 & 53.18 & 0.62 & 0.02 & 0.08 & 83.26 & 16.74 & 22.90 & 3.83 & 0.03 \\
\hline Glycine & 1.51 & 96.90 & 3.10 & 31.17 & 0.96 & 0.15 & 1.06 & 74.34 & 25.66 & 5.81 & 1.49 & 0.16 \\
\hline Glutamate & 2.90 & 97.10 & 2.90 & 11.64 & 0.34 & 0.10 & 2.04 & 74.66 & 25.34 & 4.97 & 1.26 & 0.26 \\
\hline Proline & 1.29 & 96.62 & 3.38 & 35.00 & 1.18 & 0.15 & 1.26 & 79.95 & 20.05 & 5.48 & 1.10 & 0.14 \\
\hline Serine & 1.19 & 96.69 & 3.31 & 37.72 & 1.25 & 0.15 & 0.91 & 76.56 & 23.44 & 8.02 & 1.88 & 0.17 \\
\hline Tyrosine & 0.85 & 96.39 & 3.61 & 52.57 & 1.90 & 0.16 & 0.71 & 74.07 & 25.93 & 9.61 & 2.49 & 0.18 \\
\hline
\end{tabular}




\section{Conclusions}

The analysis of amino acids of the crude protein fraction of feeds should be a laboratorial routine, since it is relatively simple and allows establishing mechanistic parameters for evaluation of feeds. The correct evaluation of feeds should consider the composition of amino acids, their degradation and intestinal digestibility, once the amino acid composition of the feed does not reflect the amino acid profile that reaches the small intestine. The individual amino acids of forage disappear in different extensions in the rumen and in the intestine. The results of these studies suggest that the protein and amino acids non-degraded in the rumen have variable intestinal digestibility.

\section{References}

AGRICULTURAL AND FOOD RESEARCH COUNCIL - AFRC. Energy and protein requeriments of ruminants. Wallingford: Commonwealth Agricultural Bureaux International, 1993, 159p.

ASSOCIATION OF OFFICIAL ANALYTICAL CHEMISTS - AOAC. Official methods of analysis. 15.ed. Arlington: AOAC International, 1990, $1117 \mathrm{p}$.

CALSAMIGLIA, S.; STERN, M.D. Three-step in vitro procedure for estimating intestinal digestion of protein in ruminants. Journal of Animal Science, v.73, n.5, p.1459-1465, 1995.

CUNNIFF, P. Official methods of analysis of AOAC International. 16.ed. Arlington: 1995. 1016p.

DAKOWSKI, P.; WEISBJERG M.R.; HVELPLUND, T. The effect of temperature during processing of rape seed meal on amino acid degradation in the rumen and digestion in the intestine. Animal Feed Science and Technology, v.58, p.213-226, n.3-4, 1996.

ERASMUS, L.J.; BOTHA, P.M.; CRUYWAGEN, C.W. et al. Amino acid profile and intestinal digestibility in dairy cows of rumenundegradable protein from various feedstuffs. Journal of Dairy Science, v.77, n.2, p.541-551, 1994.

FOX, D.G.; SNIFFEN, C.J.; O'CONNOR, J.D. et al. A net carbohydrate and protein system for evaluating cattle diets: III. Cattle requirements and diet adequacy. Journal of Animal Science, v.70, n.11, p.3578-3596, 1992.

GONZÁLEZ, J.; CENTENO, C.; MORUJO, N. et al. In situ ruminal amino acid degradability of green and ensiled Italian rye-grass according to particle transit model and microbial contamination correction. Livestock Science, v.123, n.2-3, p.209-214, 2009.

HARSTAD, O.M.; PRESTLOKKEN, E. Effective rumen degradability and intestinal indigestibility of individual amino acids in solvent- extracted soybean meal (SBM) and xylosetreated SBM (Soypass (R)) determined in situ. Animal Feed Science and Technology, v.83, n.1, p.31-47, 2000.

HVELPLUND, T.; WEISBJERG, M.R.; ANDERSEN, L.S. Estimation of the true digestibility of rumen undegraded dietary protein in the small intestine of ruminants by the mobile nylon bag technique. Acta Agriculturae Scandinavica, v.42, n.1, p.34-39, 1992.

ISHIDA, Y.; FUJITA, T.; ASAI, K. New detection and separation method for amino acids by high-performance liquid chromatography. Journal of Chromatography, v.204, n.2, p.143-148, 1981.

KOMPRDA, T.; STANDARA, S. Degradability of amino acids of lucerne hay in the rumen of cattle. Zivocisna Vyrobia, v.37, n.9, p.727-734, 1992.
LICITRA, G.; HERNANDEZ, T.M.; VAN SOEST, P.J. Standardization of procedures for nitrogen fractionation of ruminant feeds. Animal Feed Science and Technology, v.57, n.4, p.347-358, 1996.

LLAMES, C.R.; FONTAINE, J. Determination of amino acids in feeds: Collaborative study. Journal of AOAC International, v.77, n.1, p.1362-1402, 1994.

MASOERO, F.; FIORENTINI, L.; ROSSI, F. et al. Determination of nitrogen intestinal digestibility in ruminants. Animal Feed Science Technology, v.48, n.3-4, p.237-264, 1994.

MCDONALD, I. A revised model for the estimation of protein degradability in the rumen. Journal of Agricultural Science, v.96, n.1, p.251-252, 1981.

MUPETA, B.; WEISBJERG, G.M.; HVELPLUND, T. Digestibility of amino acids in protein rich tropical feeds for ruminants estimated with the mobile bag technique. Animal Feed Science and Technology, v.69, n.1-3, p. 271-280, 1997.

NATIONAL RESEARCH COUNCIL - NRC. Nutrient requirements of dairy cattle. 7.ed. Washington D.C.: National Academy Press, 2001, 356p.

NATIONAL RESEARCH COUNCIL - NRC. Nutrient requirements of sheep. 6.ed. Washington, D.C.: National Academy Press, 1985. 99p.

ORSKOV, E.R., MCDONALD, I. The estimation of protein degradability in the rumen from incubation measurements weighted according to rate of passage. Journal of Agricultural Science, v.92, n.2, p.499-503, 1979.

RULQUIN, H.; PSULEWISKI, P.M.; VÉRITÉ, R. Milk production and composition as a function of postruminal lysine and metionine supply: A nutrient-response approach. Livestock Production Science, v.37, n.1-2, p.69-90, 1993.

RULQUIN, H.; VÉRITÉ, R. Amino acid nutrition of dairy cows: productive effects and animal requirements. In: GARNSWORTHY, P.C.; COLE, D.J.A. (Eds.) Recent developments in animal nutrition. Nottingham: University Press, 1996, p.71-94.

RUSSELL, J.B.; O'CONNOR, J.D.; FOX, D.G. et al. A net carbohydrate and protein system for evaluating cattle diets. 1. Ruminal fermentation. Journal of Animal Science, v.70, n.11, p.3551-3561, 1992

SCHWAB, C.G.; BOZAK, C.K.; WHITEHOUSE, N.L. et al. Amino acid limitation and flow to the duodenum at four stages of lactation. II. Extent of lysine limitation. Journal of Dairy Science, v.75, n.12, p.3503-3512, 1992.

SKIBA, B.; WEISBJERG, M.R.; HVELPLUND, T. Rumen and total intestinal tract digestibility of protein and amino acids from different roughages, determined in situ. Journal of Animal and Feed Sciences, v.65, n.5, p.347-363, 1996.

SKÓRKO-SAJKO, H.; HVELPLUND, T.; WEISBJERG, M.R. Rumen degradation and intestinal digestibility of amino acids in diffrent roughages estimated by nylon bag techniques. Journal of Animal and Feed Sciences, v.3, n.3, p.1-10, 1994.

SNIFFEN, C.J.; O’CONNOR, J.D.; VAN SOEST, P.J. et al. A net carbohydrate and protein system for evaluating cattle diets: II. Carbohydrate and protein availability. Journal of Animal Science, v.70, n.11, p.3562-3577, 1992.

TAMMINGA, S. Protein degradation in the forestomachs of ruminants. Journal of Animal Science, v.49, n.6, p.1615-1630, 1979.

VAN SOEST, P.J.; ROBERTSON, J.B.; LEWIS, B.A. Methods for dietary fiber, neutral detergent fiber, and non-starch polysaccharides in relation to animal nutrition. Journal of Dairy Science, v.74, n.10, p.3583-3597, 1991.

VAN SOEST, P.J. Nutritional ecology of the ruminant. 2.ed. Ithaca: Cornell University Press, 1994, 476p.

WEISBJERG, M.R.; HVELPLUND, T.; HELLBERG, S. et al. Effective rumen degradability and intestinal digestibility of individual amino acids in different concentrates determined in situ. Animal Feed Science and Technology, v.62, n.2-4, p.179-188, 1996. 